Mateusz H. Ziemblicki

Uniwersytet w Biatymstoku

\title{
UWARUNKOWANIA PRAWNE NADZORU NAD LASAMI NIESTANOWIĄCYMI WŁASNOŚCI SKARBU PAŃSTWA
}

\section{Wprowadzenie}

Problematykę prawa leśnego normuje kilkanaście ustaw oraz aktów wykonawczych, z czego podstawowym aktem prawnym regulującym zasady gospodarki leśnej i stanowiącym zarazem istotę prawa leśnego jest ustawa $\mathrm{z}$ dnia 28 września 1991 roku o lasach (Dz.U. z 1991 r. Nr 101, poz. 444 z późn. zm.), zwana dalej ustawą o lasach. Zdania na temat tego, czym w istocie jest prawo leśne i jakie zajmuje ono miejsce w systemie prawa są wśród przedstawicieli nauki prawa podzielone. Według prof. B. Rakoczego, prawo leśne ze względu na swoją specyfikę podmiotowo-przedmiotową może być uznawane za kompleksową gałąź lub dziedzinę prawa. ${ }^{1}$ Zdaniem prof. W. Radeckiego, prawo leśne w systemie prawa należy traktować jako element prawa ochrony przyrody sensu largo, a tym samym zalicza on prawo leśne do części szczególnej prawa ochrony przyrody. ${ }^{2}$

Zgodnie $\mathrm{z}$ definicją ustawodawcy zawartą $\mathrm{w}$ art. 3 ustawy o lasach za las uważa się grunt o zwartej powierzchni co najmniej 0,10 ha, pokryty roślinnością leśną (uprawami leśnymi) - drzewami i krzewami oraz runem leśnym - lub przejściowo jej pozbawiony, a także grunt przeznaczony do produkcji leśnej lub stanowiący rezerwat przyrody lub wchodzący w skład parku narodowego albo wpisany do rejestru zabytków oraz inne grunty związane z gospodarką leśną (m.in. zajęte pod budynki).

Według sporząadzonego w czerwcu 2012 r. Raportu o stanie lasów w Polsce $2011^{3}$ powierzchnia wszystkich lasów w Polsce wynosiła 9143,6 tys. ha, co odpowiada lesistości kształtującej się na poziomie 29,2\% (według stanu na dzień 31 grudnia 2011 roku). W strukturze własnościowej lasów w Polsce zdecydowaną

B. Rakoczy, (w:) B. Rakoczy (red.), Wybrane problemy prawa leśnego, Warszawa 2011, s. 10-11.

W. Radecki, Ustawa o lasach. Komentarz, Warszawa 2012, s. 27-28.

Centrum Informacyjne Lasów Państwowych, Raport o stanie lasów w Polsce 2011, Warszawa 2012, s. 7, http:// www.lasy.gov.pl/dokumenty/raporty/raport-o-stanie-lasow-2011/view, (data dostępu: 30.03.2013 r.). 
większość stanowią lasy publiczne $(81,3 \%)$, do których zalicza się lasy pozostające w zarządzie PGL Lasy Państwowe (77,4\%), parków narodowych $(2,0 \%)$, należące do gmin $(0,9 \%)$ oraz inne lasy należące do Skarbu Państwa (1,0\%). Pozostałą część stanowią lasy niepubliczne $(18,7 \%)$, wśród których wyodrębnia się lasy stanowiące własność osób fizycznych $(17,6 \%)$ oraz inne lasy prywatne $(1,1 \%) .{ }^{4}$ Przedmiotem dalszych rozważań niniejszego opracowania będą uwarunkowania prawne związane z nadzorem nad lasami niestanowiącymi własności Skarbu Państwa, a więc nad lasami niepublicznymi.

Przyjmuje się, że las pełni trzy podstawowe funkcje. Po pierwsze las pełni funkcję ochronną, która wiąże się ściśle z ochroną powietrza (absorpcja zanieczyszczeń, w tym pyłów i dwutlenku węgla oraz produkcja tlenu), gleby (ograniczanie lub zatrzymywanie erozji gleb) i wód (regulacja stosunków wodnych, tworzenie odpowiedniego mikroklimatu). Po drugie spełnia funkcję produkcyjną, która polega na dostarczaniu drewna, podstawowego surowca, stanowiącego odnawialne źródło energii oraz runa leśnego). Po trzecie pełni również funkcję społeczną, która polega na tym, że z jednej strony las jest miejscem pracy, z drugiej zaś stanowi dla zdecydowanej części społeczeństwa przestrzeń odpoczynku, rekreacji czy uprawiania sportu. Prawodawca w ustawie o lasach wyraźnie podkreśla wiodącą rolę ochronnej funkcji lasu, podporządkowując jej dwie pozostałe - świadczy o tym chociażby mnogość przepisów, które służą jej realizacji, a nierzadko wiążą się one z drastycznym ograniczeniem pozostałych dwóch funkcji, nakładając na właścicieli lasów szereg obowiązków (m.in. art. 9, 10, 12, 13 ustawy o lasach). Aby wyegzekwować nałożone na właścicieli obowiązki (przede wszystkim związane z ochronną funkcją lasu), ustawodawca wprowadził instytucję nadzoru, która w przypadku lasów niestanowiących własności Skarbu Państwa pełniona jest przez starostów (art. 5 ustawy o lasach).

Nie sposób przecenić roli i znaczenia lasów niestanowiących własności Skarbu Państwa. Wynika to m.in. z udziału lasów znajdujących się w prywatnych rękach w ogólnej powierzchni leśnej poszczególnych województw, szczególnie widocznej na obszarze centralnej i wschodniej Polski. Największy udział lasów prywatnych w ogólnej powierzchni leśnej województwa występuje w województwie mazowieckim (43,8\% ogólnej powierzchni lasów województwa). Równie znaczący udział występuje na terenie województwa małopolskiego $(43,7 \%)$ i lubelskiego $(40,5 \%)$. Niewiele mniejszy udział lasów prywatnych w ogólnej powierzchni leśnej województwa występuje w województwie łódzkim $(33,7 \%)$, czy podlaskim $(32,4 \%){ }^{5}$ Często w powiatach tych województw powierzchnia lasów niepublicznych ponad dwukrotnie przekracza powierzchnię lasów publicznych. Stan ten z jednej strony jest efektem realizacji przyjętego przez Radę Ministrów 23 czerwca 1995 roku Kra- 
jowego Programu Zwiększania Lesistości, ${ }^{6}$ który zasadniczo opiera się aktualnie o nowe zalesienia właśnie na gruntach prywatnych, z drugiej zaś, na znacznym zahamowaniu na przestrzeni ostatnich lat przekazywania gruntów rolnych przez Agencję Nieruchomości Rolnych poszczególnym nadleśnictwom. Natomiast poważnymi utrudnieniami w prowadzeniu racjonalnej gospodarki leśnej jest znaczne rozdrobnienie (ponieważ przeciętna powierzchnia lasu, przypadająca na jednego właściciela stanowi w Polsce w chwili obecnej około 1,4 ha ${ }^{7}$ ) oraz duża liczba właścicieli lasów prywatnych, co stanowi poniekąd efekt, uzasadnionej m.in. względami historycznymi, niechęci właścicieli lasów prywatnych do zrzeszania się. Wszystkie powyższe czynniki powodują szereg problemów - w tym przede wszystkim natury prawnej - związanych z właściwym nadzorem nad lasami niepaństwowymi, a które będą stanowić przedmiot dalszych rozważań.

\section{System nadzoru nad gospodarką leśną w lasach niepaństwowych}

W praktyce zdecydowana większość starostów korzysta z uprawnienia wynikającego z art. 5 ust. 3 ustawy o lasach i zleca - w drodze porozumien - pełnienie nadzoru, właściwym miejscowo nadleśniczym. Fakt ten potwierdzają dane pochodzące z ewidencji Regionalnej Dyrekcji Lasów Państwowych w Białymstoku. Na jej terenie powierzchnia lasów prywatnych wynosi łącznie 218677 ha, ${ }^{8} \mathrm{z}$ czego nadzór nad powierzchnią 170827 ha (78\%) lasów niepaństwowych powierzono nadleśniczym. ${ }^{9}$ Starostowie samodzielnie pełnią nadzór nad lasami o powierzchni 47850 ha $(22 \%) .{ }^{10}$

Czym w istocie jest nadzór nad gospodarką leśną w lasach niepaństwowych syntetycznie opisał już w literaturze przedmiotu M. Geszprych, wskazując że: „Nadzór nad gospodarką leśną jest działalnością aktywną, polegającą na możliwości władczego wkraczania w działalność właścicieli lasów, w celu korygowania ich działalności. Nadzór jest czynnością prawną (wykonywaną zawsze na podstawie i w granicach prawa), dokonywaną w formie określonych środków nadzoru. Czynność ta pociąga za sobą przewidziane przepisami prawa skutki prawne, np. zmuszenie właściciela lasu do wykonywania prac pielęgnacyjnych oraz wszelkie konsekwencje prawne $\mathrm{z}$ tego faktu wynikające, np. nałożenie grzywny w przypadku niewywiązywania się z nałożonych obowiązków." 11

Ministerstwo Środowiska, Krajowy Program Zwiększania Lesistości, Aktualizacja 2003 r., Warszawa, maj 2003 r., s. 9, http://www.mos.gov.pl/artykul/326_lesnictwo/296_krajowy_program_zwiekszania_lesistosci.html, (data dostępu: 30.03.2013 r.).

$7 \quad$ P. Gołos, (w:) P. Gołos (red.), Poradnik dla właścicieli lasów, Sękocin Stary 2011, s. 12.

8 Źródło: Dane z ewidencji RDLP w Białymstoku.

9 Ibidem.

10 Ibidem.

11 M. Geszprych, (w:) P. Gołos (red.), Poradnik dla właścicieli lasów, Sękocin Stary 2011, s. 55. 
Zgodnie z przepisami ustawy o lasach zadania realizowane przez nadleśniczych w lasach niepaństwowych mogą obejmować: 1) prowadzenie powierzonych przez starostów spraw nadzoru nad gospodarką leśną (art. 5 ust. 4 ustawy o lasach), 2) pomoc udzielaną właścicielom lasów przez nadleśniczych (art. 35 ust. 2-5 ustawy o lasach), 3) wspomaganie działalności organów administracji publicznej (m.in. art. 9 ust. 2 , art. 10 ust. 1 pkt 2 , art. 12 ust. 2 pkt 2 ustawy o lasach).

Sposób realizacji zadań z zakresu nadzoru nad gospodarką leśną określają odpowiednio: 1) porozumienia zawierane ze starostami - w przypadku przejęcia nadzoru przez nadleśniczych (porozumienia te zawierają przede wszystkim zakres nadzoru, sposób jego realizacji oraz wynagrodzenie), 2) szczegółowe przepisy ustawy o lasach, rozporządzenie Ministra Środowiska, Zasobów Naturalnych i Leśnictwa z dnia 24 lutego 1998 roku w sprawie szczegółowych zasad cechowania drewna, wzorów urządzeń do cechowania i zasad ich stosowania oraz wzoru dokumentu stwierdzającego legalność pozyskiwania drewna (Dz.U. Nr 36, poz. 201) oraz odpowiednio ustalenia Krajowego Programu Zwiększania Lesistości. ${ }^{12}$

Zgodnie z obecnym brzmieniem ustawy o lasach do powierzanych przez starostów właściwym miejscowo nadleśniczym spraw z zakresu nadzoru nad gospodarką leśną w lasach niestanowiących własności Skarbu Państwa należą: 1) ustalanie zadań z zakresu wyrębu drzew, ponownego zakładania upraw leśnych, przebudowy drzewostanów, pielęgnowania i ochrony lasów, w tym również ochrony przeciwpożarowej (art. 13 ustawy o lasach), 2) nakładanie w drodze decyzji określonych zadań na właścicieli lasów niepaństwowych w przypadku niewykonywania przez nich obowiązków wynikających z art. 9 ust. 1 pkt 1-3 ustawy o lasach (art. 9 ust. 2 ustawy o lasach), 3) zarządzanie, z urzędu lub na wniosek nadleśniczego, wykonywania zabiegów ochronnych w lasach zagrożonych (art. 10 ust. 1 pkt 2 ustawy o lasach), 4) cechowanie drewna i wystawianie właścicielowi lasu dokumentu stwierdzającego legalność pozyskanego drewna (art. 14a ust. 3 ustawy o lasach), 5) określanie decyzją (na podstawie inwentaryzacji stanu lasu) zadań z zakresu gospodarki leśnej dla lasów rozdrobnionych, o powierzchni do 10 ha (art. 19 ust. 3 ustawy o lasach), 6) nadzorowanie wykonywania zatwierdzonych uproszczonych planów urządzenia lasu (art. 22 ust 5 ustawy o lasach), 7) wydawanie (na wniosek właściciela lasu) decyzji w sprawie pozyskania drewna niezgodnego z uproszczonym planem urządzenia lasu lub decyzją, o której mowa w art. 19 ust. 3 ustawy o lasach (art. 23 ust. 4 ustawy o lasach), 8) nakazywanie w drodze decyzji właścicielom lasów wykonywania obowiązków określonych w art. 13 ustawy o lasach, albo zadań zawartych w uproszczonym planie urządzenia lasu lub decyzji, o której mowa w art. 19 ust. 3 ustawy o lasach, w przypadku, gdy właściciele lasów tych obowiązków i zadań nie wykonują (art. 24 ustawy o lasach). 
Do wyłącznej kompetencji starostów (w związku z czym nie mogą być one przekazywane w drodze porozumień nadleśniczym) należą: 1) wydawanie na wniosek właściciela lasu prywatnego (po wcześniejszym zaopiniowaniu przez nadleśniczego) decyzji w sprawie przyznania środków na pokrycie kosztów, o których mowa w art. 12 ust. 1 ustawy o lasach (art. 12 ust. 2 pkt 2 ustawy o lasach), 2) wydawanie decyzji w sprawie zmiany lasu na użytek rolny na wniosek właściciela lasu o powierzchni do 10 ha (art. 13 ust. 2-3 ustawy o lasach), 3) wydawanie na wniosek właściciela lub użytkownika wieczystego gruntu - zaopiniowany wcześniej przez wójta (burmistrza, prezydenta miasta) - decyzji w sprawie przyznania środków z budżetu państwa na całkowite lub częściowe pokrycie kosztów zalesiania gruntów (art. 14 ust. 5 ustawy o lasach), 4) uznawanie lub pozbawianie charakteru ochronnego lasu (art. 16 ust. 1 pkt 1a ustawy o lasach), 5) zlecanie sporządzania uproszczonych planów urządzenia lasu dla lasów należących do osób fizycznych i wspólnot gruntowych (art. 21 ust. 1 pkt 2 ustawy o lasach), 6) zlecanie przeprowadzania inwentaryzacji stanu lasów rozdrobnionych, o powierzchni do 10 ha (art. 21 ust. 2 ustawy o lasach), 7) wydawanie decyzji w sprawie uznania lub nieuznania składanych zastrzeżeń i wniosków do wyłożonego projektu uproszczonego planu urządzenia lasu (art. 21 ust. 5 ustawy o lasach), 8) zatwierdzanie uproszczonych planów urządzenia lasu po zaopiniowaniu przez właściwego miejscowo nadleśniczego (art. 22 ust. 2 ustawy o lasach).

\section{Praktyczne problemy związane z nadzorem nad lasami niestanowiącymi własności Skarbu Państwa}

Podstawowym problemem związanym z prowadzeniem gospodarki leśnej i nadzorem nad lasami niestanowiącymi własności Skarbu Państwa jest brak uproszczonych planów urządzenia lasu (w kompleksach leśnych powyżej 10 ha) lub danych inwentaryzacji stanu lasu (w kompleksach leśnych poniżej 10 ha). Ustawodawca w wielu przepisach ustawy o lasach, przykładowo w art. 23 czy 24, uzależnia wykonywanie określonych obowiązków, czy zadań związanych z prowadzeniem gospodarki leśnej od istnienia tych dokumentów. W pierwotnym brzmieniu ustawy o lasach ustawodawca w art. 79 wyznaczył pięcioletni okres przejściowy, zadaniem którego było „zapobieżenie powstaniu luki w prawie wynikającej z braku planów urządzenia lasu (...). Przepis ten określił nie tylko to, kto i w jakim terminie jest zobowiązany do sporządzenia takich planów (ust. 1 i 2), ale także wskazał na właściwość organów w zakresie gospodarowania i ochrony lasów w czasie do przyjęcia nowych planów (ust. 3)." ${ }^{\prime 13}$ Ze względu na upływ czasu artykuł ten w kolejnych nowelizacjach ustawy o lasach został pominięty, jednakże obecnie zamieszczony 
jest w obwieszczeniu Marszałka Sejmu Rzeczypospolitej Polskiej z dnia 13 grudnia 2010 roku w sprawie ogłoszenia jednolitego tekstu ustawy o lasach (Dz.U. z 2011 r. $\mathrm{Nr}$ 12, poz. 59). Brak uproszczonych planów urządzenia lasu lub danych inwentaryzacji stanu lasu znacząco ogranicza możliwość prowadzenia nadzoru nad lasami niestanowiącymi własności Skarbu Państwa. Ograniczenie to sprowadza omawiany nadzór ipso iure jedynie do wykonywania przez właścicieli lasów niepaństwowych obowiązków samoistnych wynikających wprost z ustawy o lasach (art. 9, 13, 14a, czy 24). W praktyce jednak bardzo często realizowane są również pozostałe obowiązki - te, które wynikają z nieistniejących planów urządzenia lasu lub danych inwentaryzacji stanu lasu - w przeciwnym razie mielibyśmy bowiem do czynienia $\mathrm{z}$ absurdalnym i niedopuszczalnym rozumowaniem, sprowadzającym się do sytuacji, w której - zgodnie z literą prawa - wskutek braku wyżej wymienionych dokumentów, niemożliwym stałoby się prowadzenie zrównoważonej gospodarki leśnej i zapewnienie ciągłości użytkowania lasów niepaństwowych.

Kolejny poważny problem prawny wynika $\mathrm{z}$ niekonsekwencji ustawodawcy, która znajduje swój wyraz w nieprecyzyjnym brzmieniu art. 21 ustawy o lasach. Artykuł ten przewiduje, iż plan urządzenia lasu lub uproszczony plan urządzenia lasu dla lasów będących w zarządzie Lasów Państwowych sporządzany jest na zlecenie i koszt Lasów Państwowych (art. 21 ust. 1 pkt 1), dla lasów niestanowiących własności Skarbu Państwa, należących do osób fizycznych i wspólnot gruntowych sporządzany jest na zlecenie starosty (art. 21 ust. 1 pkt 2), a dla pozostałych lasów, na zlecenie i koszt właścicieli (art. 21 ust. 1 pkt 3). Literalne brzmienie pkt 2 ust. 1 art. 21 ustawy o lasach określa jedynie podmiot, na zlecenie którego sporządzane są te dokumenty, nie określając jednak na czyj koszt. W związku z powyższym pojawiły się przypadki kwestionowania przez Regionalne Izby Obrachunkowe zasadności ponoszenia przez starostów kosztów na opracowanie tych dokumentów, efektem czego były przypadki zaprzestania zlecania ich wykonywania.

Szereg problemów, w tym prawnych, związanych z nadzorem nad lasami niestanowiącymi własności Skarbu Państwa wykazała kontrola NIK, której efektem było opublikowanie w 2011 roku Informacji o wynikach kontroli realizacji przez starostów zadań gospodarki leśnej w lasach niestanowiących własności Skarbu Państwa. ${ }^{14}$ Z informacji tam zawartych wynika m.in., że: 1) w 6 starostwach (na 24 kontrolowane w całej Polsce) dokonano zmiany 49,74 ha lasu na użytki rolne na podstawie niepełnego i nierzetelnego materiału dowodowego, 2) w 3 starostwach odnotowano 64 przypadki zaniechania czynności egzekucyjnych wobec właścicieli lasów, którzy nie zrealizowali decyzji administracyjnych starostów i nadleśniczych, zobowiązujących do wykonania zabiegów ochronnych i hodowlanych, 3) na terenie 4 starostw stwierdzono, że 35 właścicieli lasów dokonało nielegalnego i dewastacyjnego wyid,2935,vp,3709.pdf, (data dostępu: 06.04.2013 r.). 
rębu drzewostanu - w takich przypadkach starostowie byli zobowiązani do powiadomienia organów ścigania o uzasadnionym podejrzeniu popełnienia przestępstwa lub wykroczenia, czego nie zrobili. ${ }^{15}$

Innymi problemami związanymi z prowadzeniem wyżej wymienionego nadzoru są ponadto: 1) stały niedobór środków w budżetach starostw, co skutkuje zbyt niskim poziomem stawek, który nie pozwala na pełny nadzór (w praktyce skutkuje to odstąpieniem od pełnionego przez nadleśniczych nadzoru po wyczerpaniu środków oraz odwlekaniem w czasie zlecania opracowywania uproszczonych planów urządzenia lasu oraz inwentaryzacji stanu lasu), 2) przypadki traktowania przez starostów spraw nadzoru jako mało istotne (w przypadku niezlecania nadzoru nadleśniczym, w starostwach często powierza się sprawy związane z gospodarką leśną nieodpowiednio przygotowanym pracownikom lub pracownikom bez odpowiednich kwalifikacji), 3) wspominana już we wstępie, utrudniająca nadzór fragmentacja kompleksów leśnych oraz wielka liczba właścicieli, 4) wciąż częsty brak uregulowania prawnego stosunków własnościowych nieruchomości leśnych (np. brak ksiąg wieczystych).

\section{Podsumowanie}

W świetle obecnego stanu prawnego zasadną wydaje się kolejna nowelizacja ustawy o lasach, która stworzyłaby prawne możliwości prowadzenia właściwej gospodarki leśnej w lasach niestanowiących własności Skarbu Państwa w przypadku braku uproszczonych planów urządzenia lasu, czy decyzji inwentaryzacyjnych (brak tych dokumentów stanowi duży problem w prowadzeniu trwale zrównoważonej gospodarki leśnej, co w konsekwencji może prowadzić do dewastacji lasów prywatnych). We wcześniejszym brzmieniu ustawy o lasach sytuację tę regulował art. 79, który obecnie został pominięty. Konieczne jest również doprecyzowanie, z jakich środków ma być finansowane sporządzanie uproszczonych planów urządzenia lasu lub danych inwentaryzacji stanu lasu (problem niekonsekwencji ustawodawcy w art. 21 ustawy o lasach).

Na rozwój trwale zrównoważonej gospodarki leśnej wpłynęłoby prowadzenie jej na większych obszarach. Sprzyjałoby temu zrzeszanie się właścicieli lasów w stowarzyszenia prywatnych właścicieli lasów, co z kolei ułatwiłoby pozyskiwanie środków pomocowych, w tym pochodzących z UE, które pozwoliłyby realizować programy środowiskowe, wpływające na zrównoważony rozwój. Środki te mogłyby również kompensować utracone korzyści z tytułu udostępniania tych lasów społeczeństwu, np. dla celów rekreacyjnych.

Lasy niepubliczne powinny, wzorem lasów stanowiących własność Skarbu Państwa, pełniej wypełniać wszystkie funkcje lasu trwale zrównoważonego. W praktyce 
jest to trudne do osiągnięcia ze względu na naturalną dla właścicieli prywatnych lasów chęć szybkich zysków, bez większego angażowania się w zabiegi pielęgnacyjne, rozłożone dodatkowo na wiele lat (co minimalizuje rentowność gospodarki leśnej). Jednak działania zmierzające do zwiększenia właściwego merytorycznie, skutecznego i pełnego nadzoru winny przynieść pewną poprawę stanu lasów niepublicznych, a w konsekwencji wpłynąć na zwiększenie ich roli w pełnieniu funkcji pozagospodarczych. Aby to osiągnąć niezbędne jest zwiększenie środków finansowych, jakimi dysponują starostowie na pełnienie nadzoru. Wskazane byłoby ponadto jasne określenie wszystkich kompetencji nadleśniczych - w przypadku zlecania im nadzoru, zwłaszcza ich uprawnień administracyjnych (np. do wydawania decyzji wiążących właścicieli lasów prywatnych).

Na podkreślenie $\mathrm{w}$ tym miejscu zasługuje ponadto fakt, na który nauka prawa leśnego, szerzej prawa ochrony przyrody sensu largo, czy nawet prawa ochrony środowiska, jak dotąd nie położyła należytego nacisku. Styczna, wspomnianych we wstępie, trzech klasycznych funkcji lasu (wywodzących się nie tylko z nauki leśnictwa, ale również z praktyki prowadzenia gospodarki leśnej i sięgających swymi korzeniami początków XIX wieku), tzn. ochronnej, produkcyjnej i społecznej - a więc racjonalne wyważenie nakładających się kolejno na owe funkcje lasu interesów - ekologicznych, ekonomicznych i zbiorowości - oddaje istotę zasady zrównoważonego rozwoju. W rzeczywistości jednak należy pamiętać o tym, że wyważenie tych trzech interesów jest niezwykle trudne, a wręcz niemożliwe. O ile więc pojęciem zrównoważonego rozwoju po raz pierwszy posłużono się podczas Konferencji Sztokholmskiej w 1972 roku, ${ }^{16}$ o tyle genezy tej zasady należy szukać znacznie wcześniej - przynajmniej na początku XIX wieku w nauce i praktyce niemieckiego leśnictwa, która swoje rozwinięcie i pełny wymiar znalazła w polskim leśnictwie początku XX wiek.

16 B. Wierzbowski, B. Rakoczy, Prawo ochrony środowiska. Zagadnienia podstawowe, wyd. 5, Warszawa 2012, s. 44 . 


\section{LEGAL CONDITIONS OF SUPERVISION OVER PRIVATE FORESTS}

The aim of this study is to comment on the administrative supervision over private forests in Poland, as well to analyze legal issues concerning this supervision. The role of private forests in Poland is really significant (ca. 19\% of Polish forests are private). Unfortunately, in comparison to national forests, the majority of them are neglected. This situation is influenced by many factors including: the avidity of owners, disintegration, not enough care and improper as well as incomplete supervision. Malfunctioning supervision is typically a result of insufficient financial resources. In addition, where the supervision is conducted by forest managers, formal-legal ambiguities may arise. The range and efficacy of supervision can be expanded by allocating more funds and making adjustments in current legal regulations. These actions should improve the status of private forests and also increase their anticipated role in sustainable development.

Keywords: private forests, administrative supervision, sustainable development, legal problems 